\title{
Eruberin A, a Natural Flavanol Glycoside, Exerts Anti-Fibrotic Action on Pancreatic Stellate Cells
}

\author{
Siu Wai Tsang ${ }^{\mathrm{a}}$ Hong-Jie Zhang ${ }^{\mathrm{a}}$ Ye-Gao Chen ${ }^{\mathrm{b}}$ Kathy Ka-Wai Auyeung \\ Zhao-Xiang Bian ${ }^{a}$ \\ aSchool of Chinese Medicine, Hong Kong Baptist University, Kowloon Tong, Hong Kong SAR, \\ bSchool of Chemistry and Chemical Engineering, Yunnan Normal University, Kunming, China
}

\author{
Key Words \\ Pancreatic stellate cells - Pancreatic fibrosis - Nuclear factor-kappaB - PI3K/AKT • Sonic \\ hedgehog Alpha-smooth muscle actin
}

\begin{abstract}
Background: Eruberin A (2, 3-dehydroflavonoid), a flavanol glycoside isolated from Pronephrium penangianum, has been used as a blood-nourishing folk medicine for centuries; however, it indeed possesses a variety of other health-promoting benefits including antifibrotic bioactivity. Activation of pancreatic stellate cells (PSCs) is the key initiating step in pancreatic fibrosis, which is a characteristic feature associated with chronic pancreatitis and pancreatic adenocarcinoma. Methods: The anti-fibrotic effect of eruberin A and the underlying mechanisms of its anti-fibrotic action in LTC-14 cells, which retained essential characteristics and morphological features of primary PSCs, were examined by means of real-time polymerase chain reactions, Western blotting and immunostaining. Results: The application of eruberin A $(20 \mu \mathrm{g} / \mathrm{ml})$ effectively inhibited the expression levels of fibrotic mediators namely alphasmooth muscle actin, fibronectin and type I-collagen, so as the sonic hedgehog signaling pathway components post transforming growth factor-beta $(5 \mathrm{ng} / \mathrm{ml})$ stimulation. Eruberin A treatment also led to a notable decrease in the activation of nuclear factor-kappaB (NF-KB) and the phosphorylation of phosphoinositide 3-kinase (PI3K)/serine-threonine kinase (AKT). Conclusion: Our results demonstrated that eruberin A significantly suppressed the expression levels of fibrotic mediators in PSCs, and we suggest that its anti-fibrotic mechanism was associated with an attenuation of the PI3K/AKT/NF-KB signaling pathway.
\end{abstract}

Copyright (C) 2015 S. Karger AG, Basel

Siu Wai Tsang, PhD or

Zhao-Xiang Bian, MD, PhD
School of Chinese Medicine, Hong Kong Baptist University, 3/F, SCM Building

7 Baptist University Road, Kowloon Tong, Kowloon, Hong Kong SAR (China)

E-Mail tsang@hkbu.edu.hk or bzxiang@hkbu.edu.hk 


\section{Cellular Physiology Cell Physiol Biochem 2015;36:2433-2446 \begin{tabular}{l|l} 
and Biochemistry Published online: July 27, 2015 & $\begin{array}{l}\text { C 2015 S. Karger AG, Basel } \\
\text { www.karger.com/cpb }\end{array}$ \\
\hline
\end{tabular} \\ Tsang et al.: Eruberin A Attenuates Fibrotic Mediators}

\section{Introduction}

Pancreatic fibrosis, an active dynamic process that results in irreversible morphological scarring of the pancreatic parenchyma, is often accompanied with chronic pancreatitis and desmoplastic reaction of pancreatic ductal adenocarcinoma (PDAC) [1, 2]. The activation of pancreatic stellate cells (PSCs) is suggested to be the most crucial initiating step of the progressive fibrotic cascade [1,3]. Typically, PSCs that comprising 4 to $7 \%$ of total pancreatic mass are localized at the periacinar region of the exocrine pancreas. In normal condition, they are quiescent. Upon injury or inflammatory events, these PSCs are activated as they lose their fat-droplets and transform into myofibroblast-like phenotype that can be identified with the presence of $\alpha$-smooth muscle actin ( $\alpha$-SMA or Acta2) [4, 5]. The formation of these fibrotic stress filaments subsequently elicits the cascade of tissue repairing mechanisms in response to pro-fibrotic and/or pro-inflammatory mediators such as transforming growth factor-beta (TGF- $\beta$ ) and tumor necrosis factor-alpha (TNF- $\alpha$ ) generated against tissue injury $[6,7]$.

According to recent studies, TGF- $\beta$ had been suggested to be the pivotal mediator involved in nearly all kinds of fibrotic conditions, for instance, hepatic fibrosis, pulmonary fibrosis and pancreatic fibrosis, and potently provoked the cascade of fibrotic events [8]. In fact, properties of stellate cells in the pancreas are similar to those present in other organs such as liver, kidney and lung. Once the stellate cells are activated, they produce massive extracellular matrix (ECM) proteins, namely fibronectin (FN1) and type I-collagen (COL I-1 $\alpha$ ) at the areas with active fibrogenesis for the purpose of tissue repairing as well as regeneration $[4,9]$. In the exocrine pancreas, the production of ECM proteins in an imbalanced fashion causes scarring of the pancreatic parenchyma and leads to permanent morphological damages of the organ [10]. Progressive fibrosis probably results in anatomical anomalies, organ failure and even cancer [11]. The abolishment of overwhelmed production of ECM proteins and sustained activation of PSCs is therefore crucial to the treatment of fibrogenesis and the associated impairments of pancreatic functions.

The majority of pro-fibrotic mediators that initiate fibrosis-related signaling cascades converge at the activation of nuclear factor-kappaB (NF- $\kappa \mathrm{B})$, which is the central signal transducer for regulating cell proliferation, apoptosis, developmental processes and inflammatory responses $[12,13]$. In most cells, NF- $\kappa B$ is present as a latent inactive complex when binding to its inhibitory subunit I-kappaB-alpha (IкB- $\alpha$ ) in the cytoplasm. The nuclear translocation of NF- $\mathrm{KB}$ dimers (i.e. RelA/p50) indicates its activation [14]. A number of reports demonstrated that TGF- $\beta$ is a potent inducer for the activation of NF- $\kappa B$ signaling $[15$, 16]. Previous works of our group showed that aberrant activation of NF- $\kappa B$ was observed in fibrotic and inflammatory conditions of the pancreas [17]. Sonic hedgehog (SHH) and its immediate effector glioma-associated oncogene (GLI1), which are the target genes of NF$\kappa \mathrm{B}$, were accordingly elicited in response to tissue injury and exogenous stimulation of proinflammatory mediators including TGF- $\beta$ and TNF- $\alpha[17,18]$. However, the molecular details of the tight control of NF- $\kappa$ B activation and up-regulation of SHH in fibrogenesis have yet clearly elucidated. In addition, the involvement of the phosphoinositide 3-kinase (PI3K)/ serine-threonine kinase (AKT) signaling pathway in fibrogenesis in PSCs also deserves our detailed investigation.

Natural products have been shown to provide satisfactory effects on treating and preventing many human diseases over the past few decades. Eruberin A, also known as 2, 3-dehydroflavonoid glycoside $\left(\mathrm{C}_{24} \mathrm{H}_{28} \mathrm{O}_{9}\right)$, can be extracted from the whole plant Pronephrium penangianum, a fern belongs to the Thelypteridacea e family. In fact, $P$. penangianum has been used as a folk medicine since ancient times in the Chinese population; for instance, the fronts of this fern are used for the treatment of irregular menstruation [19]. Previous phytochemical investigation demonstrated that several flavanol glycosides extracted from $P$. penangianum exerted significant antioxidant activities, particularly against diabetes-associated oxidative stress $[20,21]$. The 2, 3-dehydroflavonoid glycoside, or eruberin A, had been reported to exhibit potent cytotoxic effects on cellular proliferation of L929 fibroblasts and HeLa cells 


\section{Cellular Physiology Cell Physiol Biochem 2015;36:2433-2446 \begin{tabular}{ll|l} 
DOI: 10.1159/000430204 & $\begin{array}{l}\text { O 2015 S. Karger AG, Basel } \\
\text { www.karger.com/cpb }\end{array}$ \\
\hline
\end{tabular} \\ Tsang et al.: Eruberin A Attenuates Fibrotic Mediators}

[22]. Nevertheless, studies on the anti-fibrotic actions and molecular mechanisms of this flavanol compound are very limited though eruberin A appears to possess a variety of pharmacological activities.

The immortalized LTC-14 cell line established by Sparmann G et al had been proved to retain the essential characteristics and morphological features of primary PSCs, and therefore this line served as an ideal in vitro platform for our study on the fibrogenesisrelated mechanisms [23]. Besides, PANC-1 is a human PDAC line that possesses high levels of fibrotic markers and SHH components [18], was also employed in the current study. By utilizing these two cellular models, we aimed to elucidate the anti-fibrotic properties of eruberin $A$ and the underlying mechanisms of its anti-fibrotic actions by means of various biochemical assays such as real-time polymerase chain reaction, Western blotting and immunofluorescent staining. Our results suggest that eruberin A suppresses the expression levels of fibrotic mediators and SHH components plausibly via down-regulating the PI3K/ AKT/NF- $\kappa$ B signaling pathway. To this end, the cellular regulatory mechanism of fibrogenesis in PSCs is revealed.

\section{Materials and Methods}

\section{Structural identification of eruberin A}

Eruberin A was obtained as white needles and its molecular formula was established as $\mathrm{C}_{24} \mathrm{H}_{28} \mathrm{O}_{9}$ by time-of-flight (TOF) mass spectrometry (MS, m/z $483[\mathrm{M}+\mathrm{Na}]^{+}$) and by the analysis of the carbon-13 nuclear magnetic resonance $\left({ }^{13} \mathrm{C}-\mathrm{NMR}\right.$ and DEPT) data. The proton $\left({ }^{1} \mathrm{H}\right)$-NMR spectrum showed two singlet methyl characteristic signals at $\delta 2.60$, and 2.07, a methoxy singlet signal at $\delta 3.83$, an anomeric proton signal at $\delta$ $5.15(\mathrm{~d}, J=8.3 \mathrm{~Hz})$, and four aromatic proton doublet signals at $\delta 7.43(2 \mathrm{H}, \mathrm{d}, J=8.5 \mathrm{~Hz})$ and $6.96(2 \mathrm{H}, \mathrm{d}, J$ $=8.5 \mathrm{~Hz}$ ), suggesting a 1, 4-disubstituted ring B. The ${ }^{13} \mathrm{C}$-NMR (DEPT) and heteronuclear single quantum coherence (HSQC) spectra revealed that the compound has one 1, 4-disubstituted phenyl group and one fully substituted phenyl group and two aromatic methyl groups in the aglycone. A substructure, $-\mathrm{CH}_{-} \mathrm{CH}_{2}-$ $\mathrm{CH}-$, was also established through the spectral analysis of the ${ }^{1} \mathrm{H}^{-1} \mathrm{H}$ correlation spectroscopy (COSY) data. The chemical structure of eruberin A was thus determined as a flavan-4-ol glycoside, which was firstly reported by Tanaka et al from their extraction of Pronephrium triphyllum Hollt [24]. Eruberin A used in the current present study was provided and authenticated by Dr. Y-G Chen from Yunnan Normal University, Kunming, China.

\section{Cell line and culture condition}

Rat PSC line LTC-14 [23], provided by Prof. Robert Jaster from University Hospital of Rostock, Germany and human PDAC line PANC-1, purchased from American Type Culture Collection, USA, were respectively maintained in Iscove's Modified Dulbecco's medium (IMDM, Gibco) and Dulbecco's Modified Eagle medium (DMEM, Gibco), and routinely supplemented with 10\% fetal bovine serum (FBS, Gibco) and 1\% penicillinstreptomycin in a $5 \% \mathrm{CO}_{2}, 95 \%$ air humidified atmosphere at $37^{\circ} \mathrm{C}$. Recombinant TGF- $\beta$ and TNF- $\alpha$ utilized in the in vitro experiments were purchased from Sigma-Aldrich.

Cell viability assay

LTC-14 cells were seeded in 96-well plates at a density of $8 \times 10^{3}$ cells/well and treated with eruberin A ( 0 to $200 \mu \mathrm{g} / \mathrm{ml}$ ) for 24 hours (h). The cytotoxicity of eruberin A was evaluated in terms of mitochondrial metabolism by incubating the treated cells with 3-(4,5-cimethylthiazol-2-yl)-2,5-diphenyl tetrazolium bromide (MTT) reagent at $37^{\circ} \mathrm{C}$ for $3 \mathrm{~h}$ and then with isopropanol-hydrochloric acid at room temperature for $0.5 \mathrm{~h}$. Spectrophotometric absorbance of the samples was measured at $570 \mathrm{~nm}$ using a microplate reader (Bio-rad).

\section{Immunofluorescent staining}

LTC-14 and PANC-1 cells were seeded at a density of $1 \times 10^{5}$ cells/well onto poly-L-lysine-coated cover slips in 24-well plates, pre-incubated with recombinant TGF- $\beta$ ( $5 \mathrm{ng} / \mathrm{ml})$ and treated with or without eruberin A (20 $\mu \mathrm{g} / \mathrm{ml})$ for $24 \mathrm{~h}$. The cells were subsequently washed with phosphate buffered saline and 


\section{Cellular Physiology Cell Physiol Biochem 2015;36:2433-2446 \begin{tabular}{l|l|l} 
DOI: 10.1159/000430204 & (C) 2015 S. Karger AG, Basel
\end{tabular} and Biochemistry Published online: July 27, $2015 \quad$ www.karger.com/cpb \\ Tsang et al.: Eruberin A Attenuates Fibrotic Mediators}

fixed in ice-cold acetone:methanol $(1: 1, \mathrm{v} / \mathrm{v})$ for $20 \mathrm{~min}$. After rinsing, fixed cells were blocked with $3 \%$ bovine serum albumin, incubated with primary antibodies against $\alpha$-SMA (Abcam) overnight at $4 \stackrel{\circ}{\circ}$, and detected using FITC-conjugated anti-goat secondary antibody. Samples were then mounted with mounting medium containing 4',6-diamidino-2-phenylindole (DAPI, Sigma-Aldrich). Images were captured using the Nikon microscope and analyzed with the SPOT Advanced software.

Real-time quantitative polymerase chain reaction ( $q P C R$ )

Total RNA was extracted from LTC-14 and PANC-1 cells using TRIzol reagent (Invitrogen) according to the manufacturer's instruction and procedures described previously [25]. Two $\mu \mathrm{g}$ of RNA of each sample was transcribed into cDNA using PrimeScript RT master mix (Takara) in a total volume of $20 \mu \mathrm{l}$. The synthesized cDNA was applied to amplifications with rat- or human-specific primers for Tgf- $\beta$, Acta2, Col I- $\alpha 1$, Fn1, matrix metallopeptidase 2 (Mmp2) and Gapdh for 40 cycles in the ABI ViiA 7 real-time PCR system (Applied Biosystems) using 2X SYBR Green PCR Master Mix (Applied Biosystems). Expression of gene of interest of each sample was normalized to the endogenous control Gapdh. Fold changes were calculated using the comparative CT $\left(2^{-\Delta \Delta C T}\right)$ method. The primer sequences are listed in Table 1.

\section{Western blot analysis}

Protein from LTC-14 and PANC-1 cells was extracted in lysis buffers containing protease inhibitors on ice. For detection of NF-kB, nuclear fraction was used. Cell lysates were loaded, separated by 10 to $15 \%$ SDSpolyacrylamide gel electrophoresis and transferred onto PVDF membranes (Bio-rad) by wet electroblotting. The membranes were blocked with 5\% non-fat dry milk in Tris-buffered saline containing $0.1 \%$ Tween 20 for $1 \mathrm{~h}$ at room temperature, incubated with anti- $\alpha$-SMA (Abcam), FN1 (Novous), NF- $\kappa$ B p65 (Cell signaling), SHH, GLI1, $\beta$-ACTIN or LAMININ (Santa Cruz Biotechnology) antibodies overnight at $4{ }^{\circ} \mathrm{C}$, and subsequently incubated with corresponsive horseradish peroxidase-conjugated secondary antibodies. Proteins were visualized by utilization of an ECL kit (GE Healthcare).

\section{Sirius Red and Fast Green staining}

The amounts of collagen and non-collagenous proteins in LTC-14 cells were determined using Sirius Red/Fast Green collagen staining kit (Chondrex Inc.) according to the manufacturer's instruction. In brief, collagen proteins in LTC-14 cells were stained with Sirius Red whereas non-collagenous proteins were stained with Fast Green. With the addition of dye extraction solution, color was eluted from the cells. Absorbance at $540 \mathrm{~nm}$ and $640 \mathrm{~nm}$ were taken respectively for the amount of collagen and noncollagenous proteins. Data were expressed as a ratio of collagen proteins to total proteins.

Depletion of Shh by RNA interference (RNAi) in LTC-14 cells

Small interfering (siRNA) duplex specifically targeting rat Shh (sense: 5'-GCC GAU AUG AAG GGA AGA U-3'; anti-sense: 5'-AUC UUC CCU UCA UAU CGG C-3') and a non-silencing control duplex (sense: 5'-GCC AUG UAA GGA GAG AGA U-3'; antisense: 5'-AUC UCU CUC CUU ACA UGG C-3') were purchased from Invitrogen [17]. Twenty-four hours before transfection, LTC-14 cells were seeded in 24well plates at a density of $1 \times 10^{5}$ cells/well in 0.5 $\mathrm{ml}$ complete culture medium without antibiotics. The siRNA oligos at $25 \mathrm{nM}$ were delivered into the cells using Lipofectamine 2000 (Invitrogen). The silencing effects were examined by means of qPCR and Western blotting.

Table 1. List of primer sequences designed for the qPCR approach in the in vitro experiment

\begin{tabular}{ll}
\hline Primer & Sequence \\
\hline Shh_forward & 5'-GAA AGC AGA GAA CTC CGT GGC GG-3' \\
Shh_reverse & 5'-AGC AGC TGC GAG TAC CAG TGG AT-3' \\
Acta2_forward & 5'-AGA GTG GAG AAG CCC AGC CAG TC-3' \\
Acta2_reverse & 5'-GGG CCA CGC GAA GCT CGT TAT AG-3' \\
Tgf- $\beta$ _forward & 5'-GCA GTG GCT GAA CCA AGG AGA CG-3' \\
Tgf- $\beta$ _reverse & 5'-GCC CCA GAC AGA AGT TGG CAT GG-3' \\
Col I- $\alpha$ 1_forward & 5'-CAG GCG AAC AAG GTG ACA GAG GC-3' \\
Col I- $\alpha 1$ reverse & 5'-GGT TGC AGC CTT GGT TAG GGT CG-3' \\
Fn1_forward & 5'-ATC ACC TGG ACC CCC GCT CC-3' \\
Fn1_reverse & 5'-CGG TTC CCT GCT GCC CGT TT-3' \\
Mmp2_forward & 5'-CAA GTT CCC GTT CCG CTT CCA GG-3' \\
Mmp2_reverse & 5'-TAG GGG CCA TCA AAG CTC CAG GG-3' \\
Gapdh_forward & 5'-AGA GAG AGG CCC TCA GTT GCC TG-3' \\
Gapdh_reverse & 5'-AGG CCC CTC CTG TTG TTA TGG GG-3' \\
GAPDH_forward & 5'-CGA GAT CCC TCC AAA ATC AA-3' \\
GAPDH_reverse & 5'-TTC ACA CCC ATG ACG AAC AT-3' \\
TGF- $\beta$ _forward & 5'-GCC GAC TAC TAC GCC AAG GAG GT-3' \\
TGF- $\beta$ _reverse & 5'-ATT TCC CCT CCA CGG CTC AAC CA-3' \\
COL I- $\alpha 1$ forward & 5'-TAA CCC CCT CCC CAG CCA CAA AG-3' \\
COL I- $\alpha 1$ 1_reverse & 5'-CCA GTG TCT CCC TTG GGT CCC TC-3' \\
\hline &
\end{tabular}




\section{Cellular Physiology Cell Physiol Biochem 2015;36:2433-2446 \begin{tabular}{l|l|l}
\hline DOI: 10.1159/000430204 & (C) 2015 S. Karger AG, Basel
\end{tabular}

Statistical analysis

The statistical differences were determined using one-way analysis of variance (ANOVA) followed by Tukey's test as a post hoc test. All values are expressed as means \pm standard derivation (S.D.). $P$ value of $<$ 0.05 is accepted as statistically significant.

\section{Results}

NMR analysis data

In comparison with the literature data, the natural compound used in our study was identified as the known flavan-4-ol glycoside, eruberin A (Fig. 1): ${ }^{1} \mathrm{H}-\mathrm{NMR}\left(\mathrm{CD}_{3} \mathrm{OD}, 500 \mathrm{MHz}\right)$ $\delta 7.43\left(2 \mathrm{H}, \mathrm{d}, J=8.5 \mathrm{~Hz}, \mathrm{H}-2^{\prime}, 6^{\prime}\right), 6.96\left(2 \mathrm{H}, \mathrm{d}, J=8.5 \mathrm{~Hz}, \mathrm{H}-3^{\prime}, 5^{\prime}\right), 5.15$ (1H, d, $\left.J=8.3 \mathrm{~Hz}, \mathrm{H}-1^{\prime \prime}\right)$, $5.10(1 \mathrm{H}, \mathrm{m}, \mathrm{H}-4), 4.97(1 \mathrm{H}, \mathrm{d}, J=4.3 \mathrm{~Hz}, \mathrm{H}-2), 4.64(1 \mathrm{H}, \mathrm{s}, \mathrm{OH}), 3.91,3.68$ (2H, m, H-6"), 3.83 $\left(3 \mathrm{H}, \mathrm{s}, \mathrm{OCH}_{3}\right), 3.62$ (1H, m, H-3"), 3.38 (1H, m, H-5"), 3.36 (1H, m, H-2"), 3.19 (1H, m, H-4"), $2.60\left(3 \mathrm{H}, \mathrm{s}, 6-\mathrm{CH}_{3}\right), 2.32,2.00(2 \mathrm{H}, \mathrm{m}, \mathrm{H}-3), 2.07\left(3 \mathrm{H}, \mathrm{s}, 8-\mathrm{CH}_{3}\right) ;{ }^{13} \mathrm{C}-\mathrm{NMR}\left(\mathrm{CD}_{3} \mathrm{OD}, 125 \mathrm{MHz}\right) \delta$ 161.2 (s, C-4'), 156.4 (s, C-7), 153.2 (s, C-9), 151.7 (s, C-5), 135.2 (s, C-1'), 129.1 (d, C-2', 6'), 115.2 (d, C-3', 5'), 111.5 (s, C-6), 109.8 (s, C-8), 105.7 (s, C-10), 103.0 (d, C-1"), 79.3 (d, C-5"), 77.1 (d, C-3"), 76.3 (d, C-2"), 75.1 (d, C-2), 72.2 (d, C-4"), 67.5 (d, C-4), 63.4 (t, C-6”), 56.2 (q, $\left.\mathrm{OCH}_{3}\right), 38.7(\mathrm{t}, \mathrm{C}-3), 9.9\left(\mathrm{q}, 6-\mathrm{CH}_{3}\right), 9.0\left(\mathrm{q}, 8-\mathrm{CH}_{3}\right)$.

LTC-14 cells responded to pro-fibrotic agents

From the MTT cell viability assay, we found that recombinant TGF- $\beta$ and TNF- $\alpha$ (1 to $20 \mathrm{ng} / \mathrm{ml}$ ) slightly but not significantly accelerated or lowered the growth rate of LTC-14 cells (Fig. 2a). By means of qPCR, we noticed that the challenge of TGF- $\beta$ concentrationdependently increased the transcript levels of Acta2, Tgf- $\beta$ and Col I- $\alpha 1$; however, Mmp2, which encodes a major endopeptidase for modulating ECM degradation, was unaffected (Fig. 2b). The minimum effective stimulatory concentration of TGF- $\beta$ in LTC-14 cells was determined to be $5 \mathrm{ng} / \mathrm{ml}$. In order to validate the responsiveness, LTC-14 cells were also subjected to stimulation of TNF- $\alpha$. From the qPCR result, we demonstrated that the challenge of TNF- $\alpha$ also led to an augmentation of Acta2 similar to the effect of TGF- $\beta$ (Fig. 2c).

Cytotoxicity and anti-fibrotic effects of eruberin A in LTC-14 cells

The cytotoxicity of eruberin A was evaluated in terms of mitochondrial metabolism utilizing the MTT cell viability assay. LTC-14 cells were treated with eruberin A at various concentrations $(0,1,10,25,50,100$ or $200 \mu \mathrm{g} / \mathrm{ml})$ for 24 and $48 \mathrm{~h}$. The results demonstrated that the growth rates of LTC-14 cells were decreased in response to the treatment of eruberin $A$ in a dose-dependent manner. The $\mathrm{LD}_{50}$ of eruberin A in LTC-14 cells was approximately $140 \mu \mathrm{g} / \mathrm{ml}$ (Fig. 3a). By means of qPCR, we showed that the mRNA levels of Acta2, Tgf- $\beta$, Col $I-1 \alpha$ and Fn1 in LTC-14 cells decreased with the increasing concentrations of eruberin A (Fig. $3 b$ ). As the $L_{50}$ of eruberin A was roughly $140 \mu \mathrm{g} / \mathrm{ml}$, the anti-fibrotic properties of eruberin $A$ at concentrations of $20 \mu \mathrm{g} / \mathrm{ml}$ or lower in our experiments were not due to its cytotoxic effects.

Eruberin A suppressed TGF- $\beta$-induced elevation of fibrogenic mediators in pancreatic cells

Previous studies had revealed that TGF- $\beta$ plays an important role in driving PSC activation and fibrotic events. In this study,

Fig. 1. Chemical structure of eruberin A. The molecular formula of eruberin $\mathrm{A}$ is determined as $\mathrm{C}_{24} \mathrm{H}_{28} \mathrm{O}_{9}$ by TOF-MS.

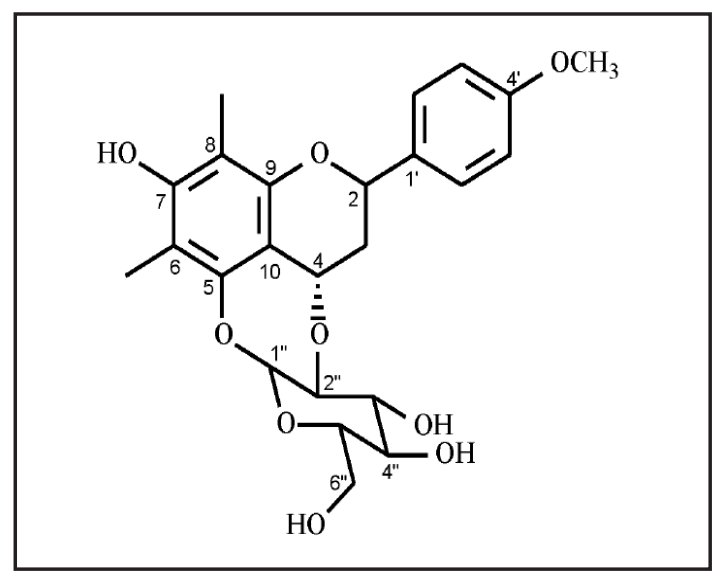


a

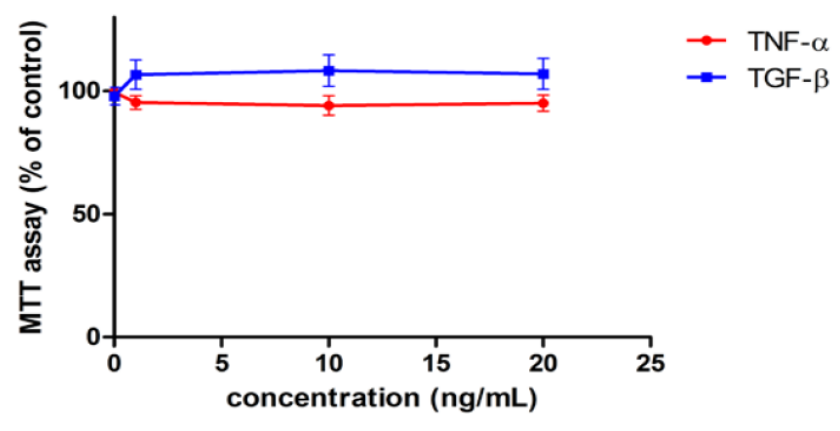

b

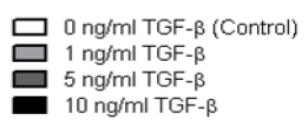

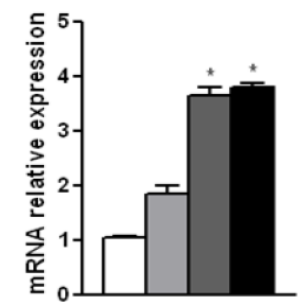

Tgf- $\beta$

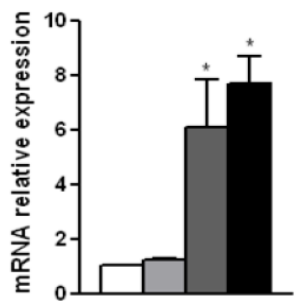

Acta2

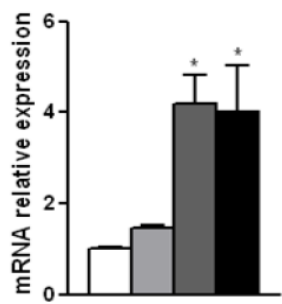

$\mathrm{Col} / \mathrm{- \alpha 1}$

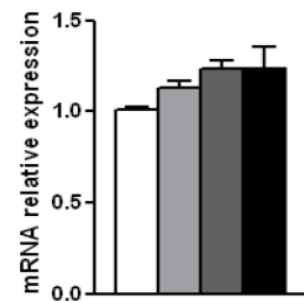

Mmp2

c

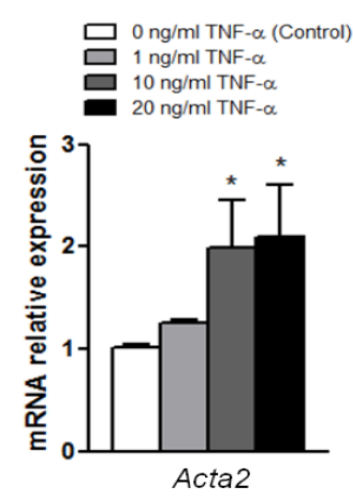

Fig. 2. LTC-14 cells respond to pro-fibrotic agents. (a) By means of MTT assay, effects of recombinant TGF- $\beta$ and TNF- $\alpha$ on proliferation of LTC-14 cells were determined. (b) Transcripts of Acta2, Tgf- $\beta$, Col I- $\alpha 1$ and Mmp2 were amplified by means of qPCR, normalized to the endogenous reference Gapdh and expressed as fold changes over the non-TGF- $\beta$-treated control. Data was collected from 4 individual experiments and expressed as mean \pm S.D. ${ }^{*} \mathrm{p}<0.05$ when comparing to control. (c) Transcripts of Acta2 were amplified by means of qPCR, normalized to the endogenous reference Gapdh and expressed as fold changes over the nonTNF- $\alpha$-treated control. Data was collected from 4 individual experiments and expressed as mean \pm S.D. ${ }^{*} \mathrm{p}<$ 0.05 when comparing to control.

we examined whether eruberin A could inhibit TGF- $\beta$-induced fibrogenesis in LTC-14 cells. By means of qPCR, transcripts of fibrogenic genes including Acta2, Tgf- $\beta$, Col I-1 $\alpha$ and Fn1 were examined. As shown in Figures $4 \mathrm{a}-\mathrm{d}$, TGF- $\beta$ remarkably elevated the mRNA levels 
a

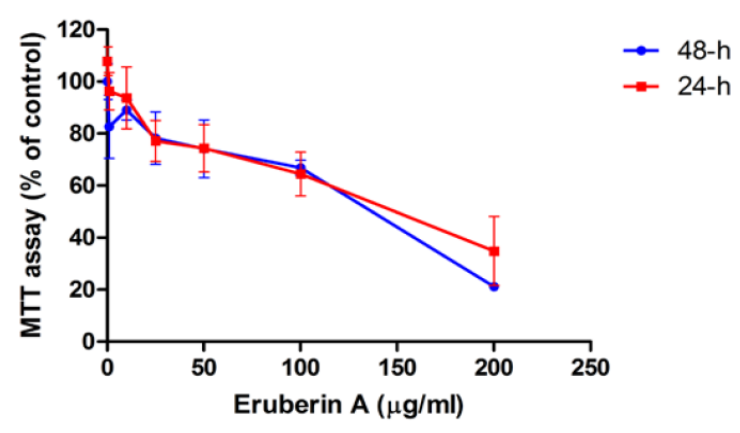

$\mathrm{b}$
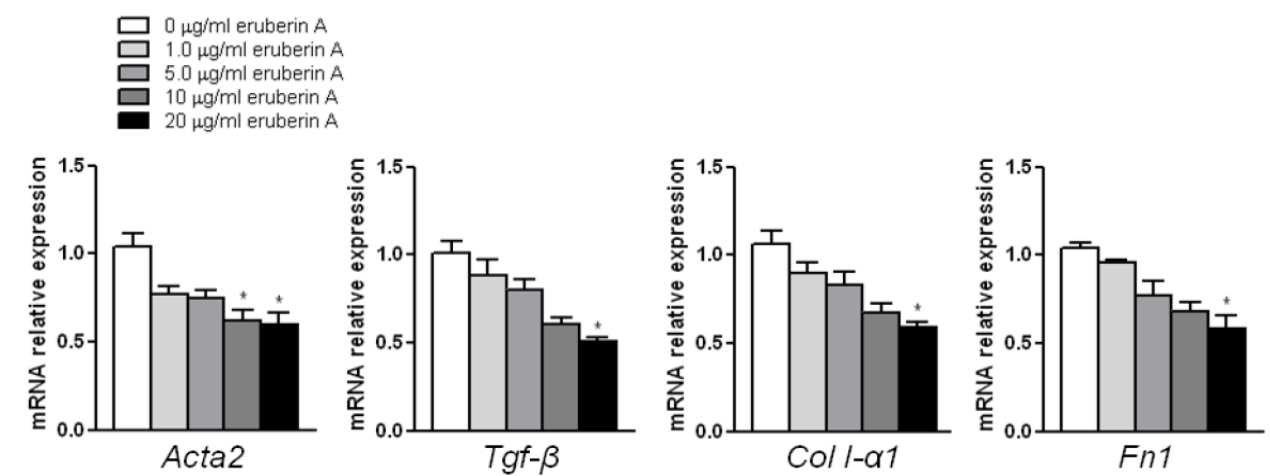

Fig. 3. Cytotoxicity and suppressive effects of eruberin A in LTC-14 cells. (a) Cytotoxicity of eruberin A was assessed in terms of mitochondrial metabolism using the MTT assay. LTC-14 cells were treated with eruberin $\mathrm{A}$ at the indicated concentrations for 24 to $48 \mathrm{~h}$ prior to the MTT assay. The $\mathrm{LD}_{50}$ of eruberin A was approximately $140 \mu \mathrm{g} / \mathrm{ml}$. (b) LTC-14 cells were treated with eruberin A (0, 1, 5, 10 or $20 \mu \mathrm{g} / \mathrm{ml}$ ) for $24 \mathrm{~h}$ and harvested for mRNA extraction. Transcripts of Acta2, Tgf- $\beta$, Col I- $\alpha 1$ and Fn 1 were amplified by means of qPCR, normalized to the endogenous reference Gapdh and expressed as fold changes over the non-eruberin A-treated control. Data was collected from 4 individual experiments and expressed as mean \pm S.D. ${ }^{*} \mathrm{p}<$ 0.05 when comparing to control.

of Acta2, Tgf- $\beta$, Col I- $1 \alpha$ and Fn1 in LTC-14 cells, and eruberin A at $20 \mu \mathrm{g} / \mathrm{ml}$ significantly reversed all of the TGF- $\beta$-inducing effects. Similar suppressive effects of eruberin A treatment on expression of TGF- $\beta$ and COL I- $1 \alpha$ were also observed in PANC- 1 cells (Fig. 4e-f). By means of Western blotting, protein levels of $\alpha$-SMA and FN1 in LTC-14 cells were determined. As shown in Figure 5a, eruberin A counter-balanced the TGF- $\beta$-induced elevation of FN1 and $\alpha$-SMA, and the trend in Western blotting was consistent with our qPCR results. On the other hand, the production of COL I- $1 \alpha$ protein was evaluated using Sirius Red/Fast Green staining. The amount of Sirius Red-stained collagenous proteins was nearly doubled by the challenge of TGF- $\beta$ at $5 \mathrm{ng} / \mathrm{ml}$ and such stimulation was repressed in the presence of eruberin A at $20 \mu \mathrm{g} / \mathrm{ml}$ (Fig. 5b). In addition, the levels of cytoplasmic $\alpha$-SMA filaments in LTC-14 cells (Fig. 5c) and PANC-1 cells (Fig. 5d) were enhanced when incubated with TGF- $\beta$ ( $5 \mathrm{ng} / \mathrm{ml})$ and such enhancements were attenuated by eruberin A $(20 \mu \mathrm{g} / \mathrm{ml})$ as demonstrated by immunofluorescence. Taken together, our results revealed that eruberin A suppressed TGF$\beta$-induced fibrogenic mediators in pancreatic cells. 
a

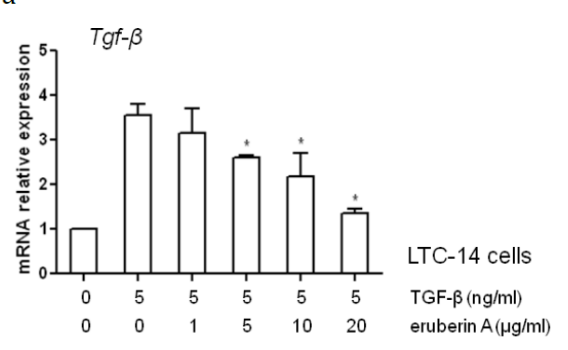

c

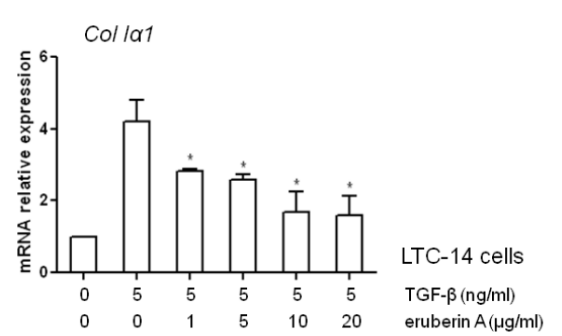

$\mathrm{b}$

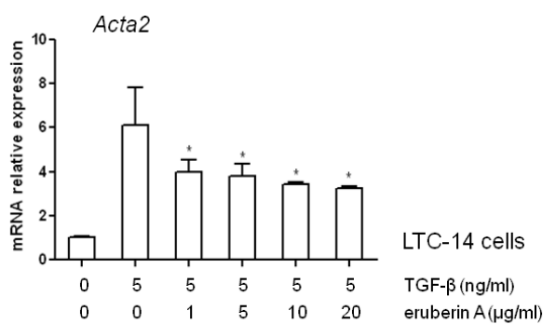

d

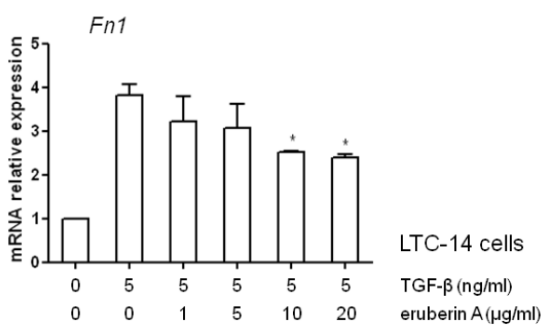

$\mathrm{f}$

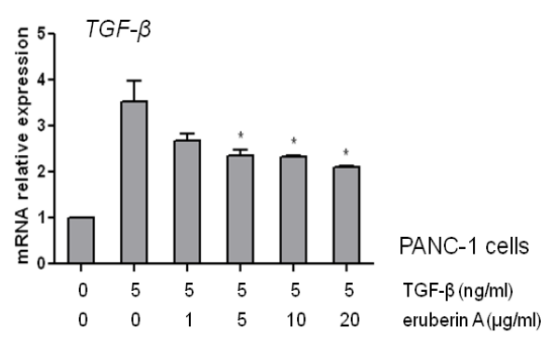

Fig. 4. Anti-fibrotic effects of eruberin A in LTC-14 and PANC-1 cells. LTC-14 cells were pre-incubated with or without TGF- $\beta(5 \mathrm{ng} / \mathrm{ml})$ for $2 \mathrm{~h}$ and treated with eruberin $\mathrm{A}(0,1,5,10$ and $20 \mu \mathrm{g} / \mathrm{ml})$ for $24 \mathrm{~h}$ prior to mRNA extraction. Transcripts of Tgf- $\beta$ (a), Acta2 (b), Col I- $\alpha 1$ (c) and Fn1 (d) were amplified by means of qPCR and normalized to the endogenous reference Gapdh. Data was collected from 4 individual experiments and expressed as mean \pm S.D. ${ }^{*} \mathrm{p}<0.05$ when comparing to TGF- $\beta$ treatment in the absence of eruberin A. PANC- 1 cells were pre-incubated with or without TGF- $\beta(5 \mathrm{ng} / \mathrm{ml})$ for $2 \mathrm{~h}$ and treated with eruberin A $(0$, $1,5,10$ and $20 \mu \mathrm{g} / \mathrm{ml}$ ) for $24 \mathrm{~h}$ prior to mRNA extraction. Transcripts of COL I- $\alpha 1$ (e) and TGF- $\beta$ (f) were amplified by means of qPCR and normalized to the endogenous reference GAPDH. Data was collected from 4 individual experiments and expressed as mean \pm S.D. ${ }^{*} \mathrm{p}<0.05$ when comparing to TGF- $\beta$ treatment in the absence of eruberin A.

Eruberin A down-regulated the activation of $N F-\kappa B$ and SHH signaling components

A number of reports had shown that NF- $\kappa B$ activation promotes fibrotic events, we therefore examined whether eruberin A inhibits this pivotal transcription factor in LTC14 cells. Our Western blotting results demonstrated that the expression of the NF- $\mathrm{BB}$ p65 subunit in the nuclear fraction was attenuated by eruberin A, particularly at concentration of $20 \mu \mathrm{g} / \mathrm{ml}$ (Fig. 6a). Upon the stimulation of TGF- $\beta$ ( $5 \mathrm{ng} / \mathrm{ml})$, the expression levels of SHH and GLI1 were notably elevated. The addition of eruberin A (20 $\mathrm{\mu g} / \mathrm{ml})$ significantly suppressed SHH signaling pathway components in both LTC-14 (Fig. 6b) and PANC-1 cells (Fig. 6c). To further assess the involvement of SHH signaling pathway in fibrogenesis, Shh was depleted 


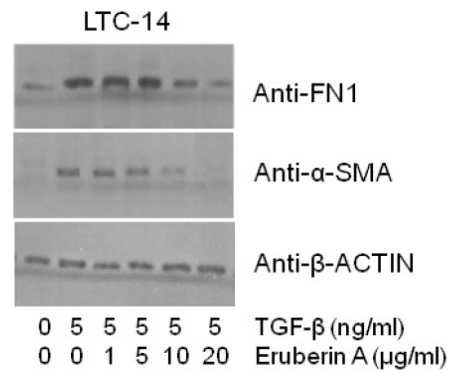

b

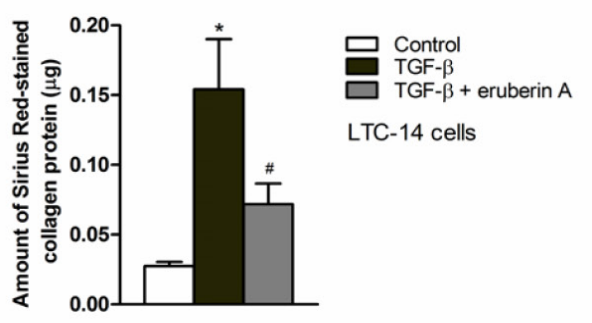

c

LTC-14

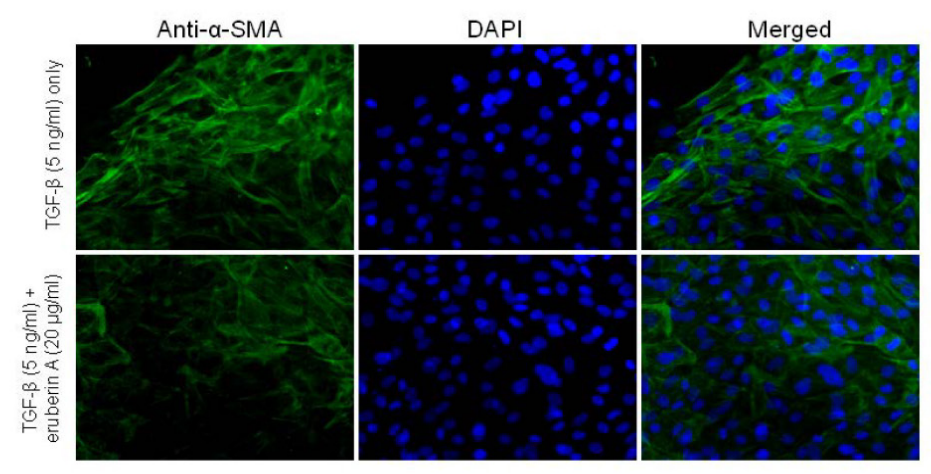

d

PANC-1

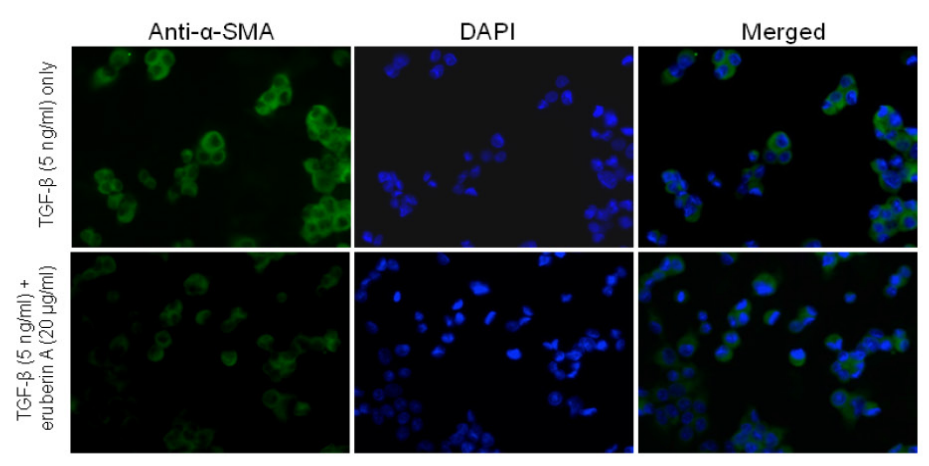

Fig. 5. Eruberin A attenuated fibrotic mediators in vitro. LTC-14 cells were pre-incubated with or without TGF- $\beta$ ( $5 \mathrm{ng} / \mathrm{ml}$ ) for $2 \mathrm{~h}$ and treated with eruberin $\mathrm{A}(0,1,5,10$ and $20 \mu \mathrm{g} / \mathrm{ml})$ for $24 \mathrm{~h}$ prior to Western blotting analysis (a) or Sirius Red/Fast Green staining (b). For Western blotting, immunoblots were probed with anti-FN1, $\alpha$-SMA and $\beta$-ACTIN antibodies, and $\beta$-ACTIN was served as a loading reference. For Sirius Red/ Fast Green staining, collagen proteins were stained with Sirius Red whereas non-collagenous proteins were stained with Fast Green. Color was eluted from the cells and measured at $540 \mathrm{~nm}$ and $640 \mathrm{~nm}$. Data was collected from 3 individual experiments and expressed as mean \pm S.D. ${ }^{*} \mathrm{p}<0.05$ when comparing to the TGF- $\beta$ treatment in the absence of eruberin A. LTC-14 cells (c) or PANC-1 cells (d) were pre-incubated with TGF- $\beta$ $(0$ or $5 \mathrm{ng} / \mathrm{ml}$ ) for $2 \mathrm{~h}$ and treated with eruberin $\mathrm{A}(20 \mu \mathrm{g} / \mathrm{ml})$ for $24 \mathrm{~h}$ prior to immunofluorescent staining for $\alpha$-SMA. Immunoreactivities of $\alpha$-SMA were visualized by FITC (green) whereas nuclei were stained blue with DAPI at magnification $200 \times$.

in LTC-14 cells by RNAi. Our qPCR results indicated that the expression levels of fibrotic filament Acta2 and Shh were significantly decreased by the transfection of siRNA duplex (25 nM) specifically targeting rat Shh in LTC-14 cells, but not by the non-silencing control

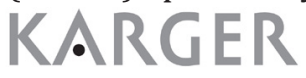




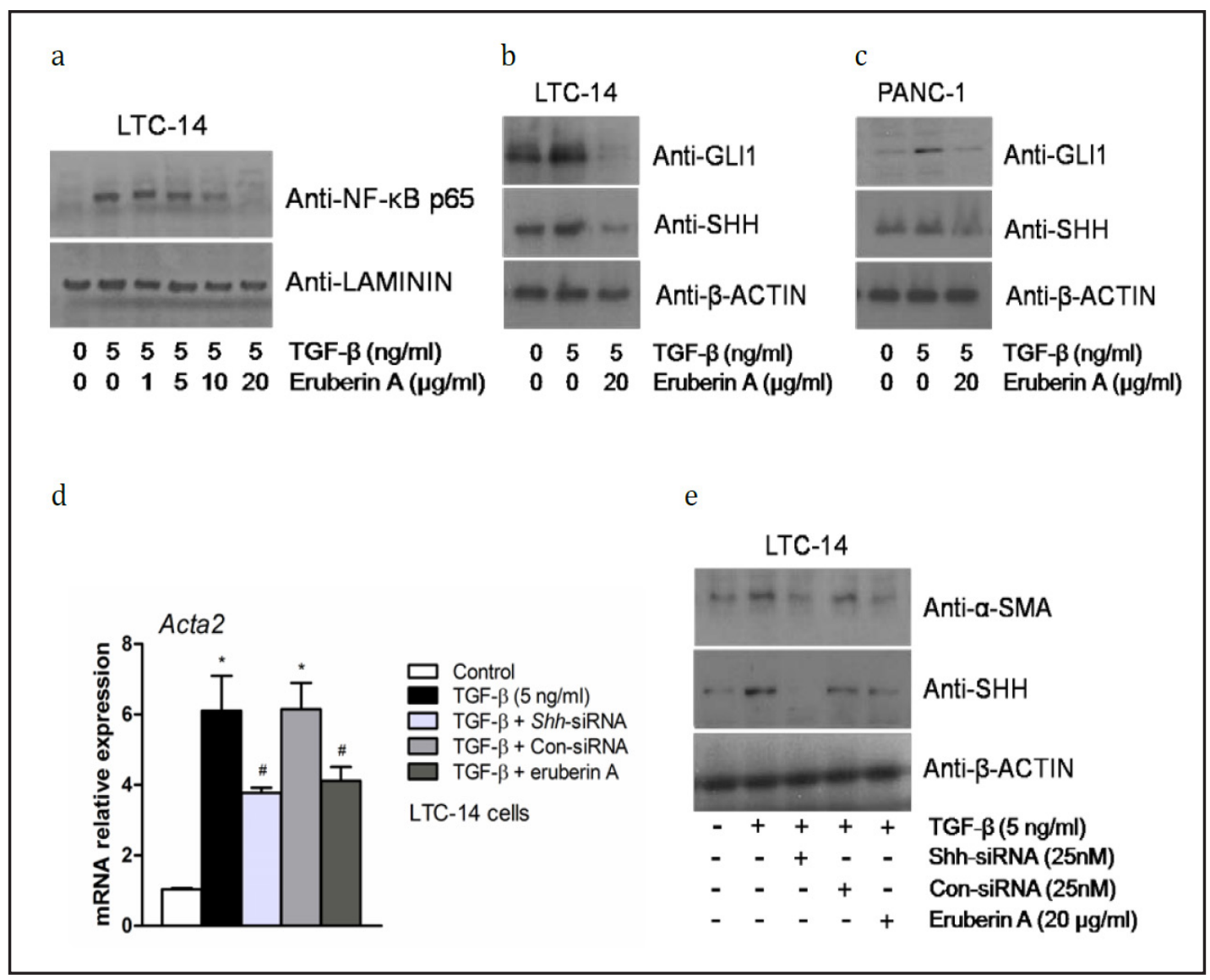

Fig. 6. Eruberin A inhibited NF- $\kappa B$ and SHH signals in vitro. (a) LTC-14 cells were pre-incubated with TGF- $\beta$ $(0$ or $5 \mathrm{ng} / \mathrm{ml})$ for $2 \mathrm{~h}$ and treated with eruberin $\mathrm{A}(0,1,5,10$ and $20 \mu \mathrm{g} / \mathrm{ml})$ for $24 \mathrm{~h}$ prior to nuclear protein extraction. Immunoblots were probed with anti-NF- $\mathrm{B}$ p 65 and LAMININ antibodies. LAMININ was served as a loading reference for the nuclear fractions. LTC-14 cells (b) or PANC-1 cells (c) were pre-incubated with TGF- $\beta$ ( 0 or $5 \mathrm{ng} / \mathrm{ml}$ ) for $2 \mathrm{~h}$ and treated with eruberin A ( $20 \mu \mathrm{g} / \mathrm{ml}$ ) for $24 \mathrm{~h}$ prior to cytoplasmic protein extraction. Immunoblots were probed with anti-SHH, GLI1 or $\beta$-ACTIN antibodies. $\beta$-ACTIN was served as a loading reference. LTC-14 cells were transfected with siRNA duplex targeting Shh (25 nM) or the non-silencing control duplex ( $25 \mathrm{nM}$ ) for $24 \mathrm{~h}$ prior to the incubation of TGF- $\beta$ ( $5 \mathrm{ng} / \mathrm{mL}$ ) with or without treatment of eruberin A (20 $\mu \mathrm{g} / \mathrm{ml})$. By means of qPCR (d) or Western blotting (e), expression levels of Acta2 ( $\alpha$-SMA) and SHH were determined.

siRNA duplex at the same concentration. The suppressive effect of eruberin A on Acta2 was comparable to the knockdown effect of the Shh-specific siRNA oligos (Fig. 6d). The silencing effect of the siRNA oligos and the suppressive effect of eruberin A on the protein levels of $\alpha$-SMA and SHH were shown in Figure 6e.

Eruberin A suppressed the activation of the PI3K/AKT pathway

The serine-threonine kinase AKT, a downstream effector of PI3K, is generally involved in cell survival, inflammatory and fibrotic cascades. In this study, we observed that AKT phosphorylation was increased after LTC-14 cells were treated with TGF- $\beta$ (5 ng/ $\mathrm{ml})$. The application of eruberin A $(20 \mu \mathrm{g} / \mathrm{ml})$ notably inhibited the TGF- $\beta$-induced AKT phosphorylation (Fig. 7a). To examine whether the PI3K/AKT signaling pathway plays an important role in fibrogenesis, LY294002 (a PI3K inhibitor) and SC-66 (an allosteic AKT inhibitor) were applied. The Western blots showed that both LY294002 $(10 \mu \mathrm{M})$ and SC-66 $(10 \mu \mathrm{M})$ remarkably reduced the TGF- $\beta$-elevated levels of $\alpha$-SMA and SHH in LTC-14 cells (Fig. 
7b). This finding suggested that the PI3K/AKT signaling pathway is involved in pancreatic fibrogenesis. In addition, both LY294002 (10 $\mu \mathrm{M})$ and SC-66 $(10 \mu \mathrm{M})$ could also inhibit the TGF- $\beta$-induced nuclear translocation of $\mathrm{NF}-\kappa \mathrm{B}$; thus, NF- $\kappa \mathrm{B}$ modulation is associated with the PI3K/AKT pathway in the fibrotic responses of PSCs (Fig. 7c).

\section{Discussion}

Fibrogenesis is described as a dynamic process that leads to the formation of fibers or fibrous substances, and plausibly plays important roles in the progression of cancer. In the pancreas, fibrosis is commonly associated with the activation of PSCs in response to tissue injury or inflammation. Upon activation, PSCs produce massive ECM proteins namely FN1 and COL I- $\alpha 1$ for the purpose of tissue repairing. The overwhelmed deposition of ECM causes scarring of the parenchyma, which is replaced by connective tissues [4, 9]. The progressive fibrotic phenomenon indeed results in permanent morphological damages and subsequent anatomical anomalies, organ failure and cancer $[1,2]$. Thus, targeting PSC activation is believed to be a novel therapeutic approach for treating and/or preventing pancreatic fibrosis, pancreatitis and PDAC.

The natural compound eruberin A is a 2 , 3-dehydroflavonoid glycoside isolated from the fern $P$. penangianum. The fronts of this fern have been used as a folk medicine for the management of irregular menstruation in the Chinese population for centuries [19]. In this study, we found that eruberin A actually possesses strong anti-fibrotic activities as it effectively suppressed the production of fibrotic filaments and ECM proteins in TGF- $\beta$ induced LTC- 14 and PANC- 1 cells while TGF- $\beta$ had been reported in a number of in vitro and in vivo studies as one of the most potent profibrotic inducers $[8,10]$. In accordance with the earlier findings, commitment with the increased production of fibrotic mediators was the up-regulation of SHH signaling upon the administration of TGF- $\beta[9,10,16]$. The present study extends the previous work of our group on the positive role of SHH signaling in promoting the synthesis of fibrotic mediators as we reported that aberrant SHH a

LTC-14

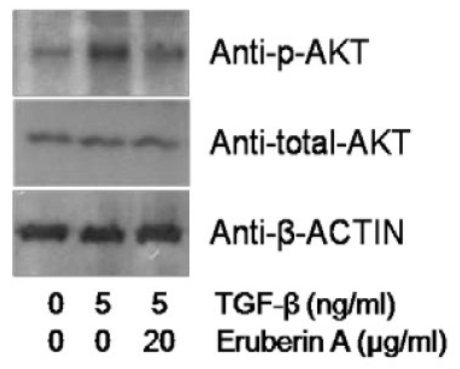

b

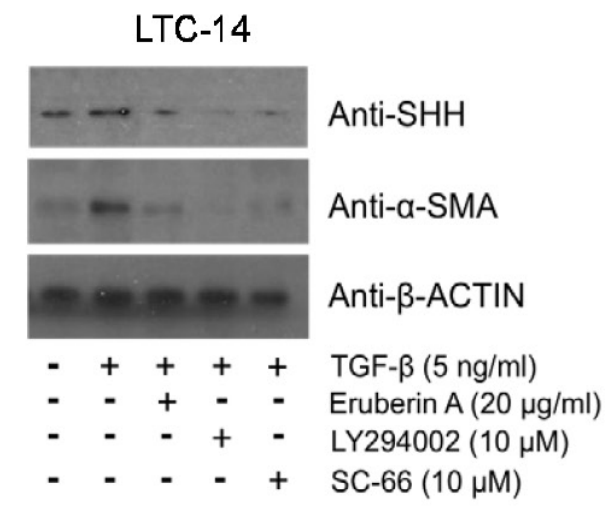

C

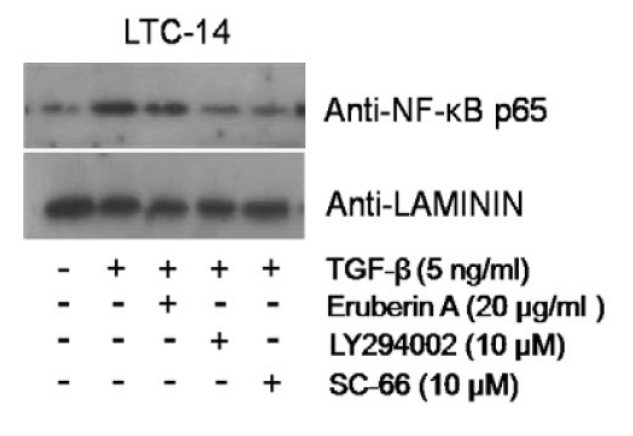

Fig. 7. Eruberin A suppressed the activation of the PI3K/AKT pathway. LTC-14 cells were pre-incubated with TGF- $\beta$ ( 0 or $5 \mathrm{ng} / \mathrm{ml}$ ) for $2 \mathrm{~h}$ and treated with eruberin A $(20 \mu \mathrm{g} / \mathrm{ml})$ or LY294002 $(10 \mu \mathrm{M})$ or SC-66 $(10 \mu \mathrm{M})$ for $24 \mathrm{~h}$ prior to protein extraction. Immunoblots were probed with antibodies against p-AKT, total AKT (a), $\alpha$-SMA, SHH (b) and NF-кB p65 (c). $\beta$-ACTIN and LAMININ were served as loading references for the cytoplasmic and nuclear extracts respectively. 
Fig. 8. Schematic presentation of the signaling pathways involved in pancreatic fibrogenesis.

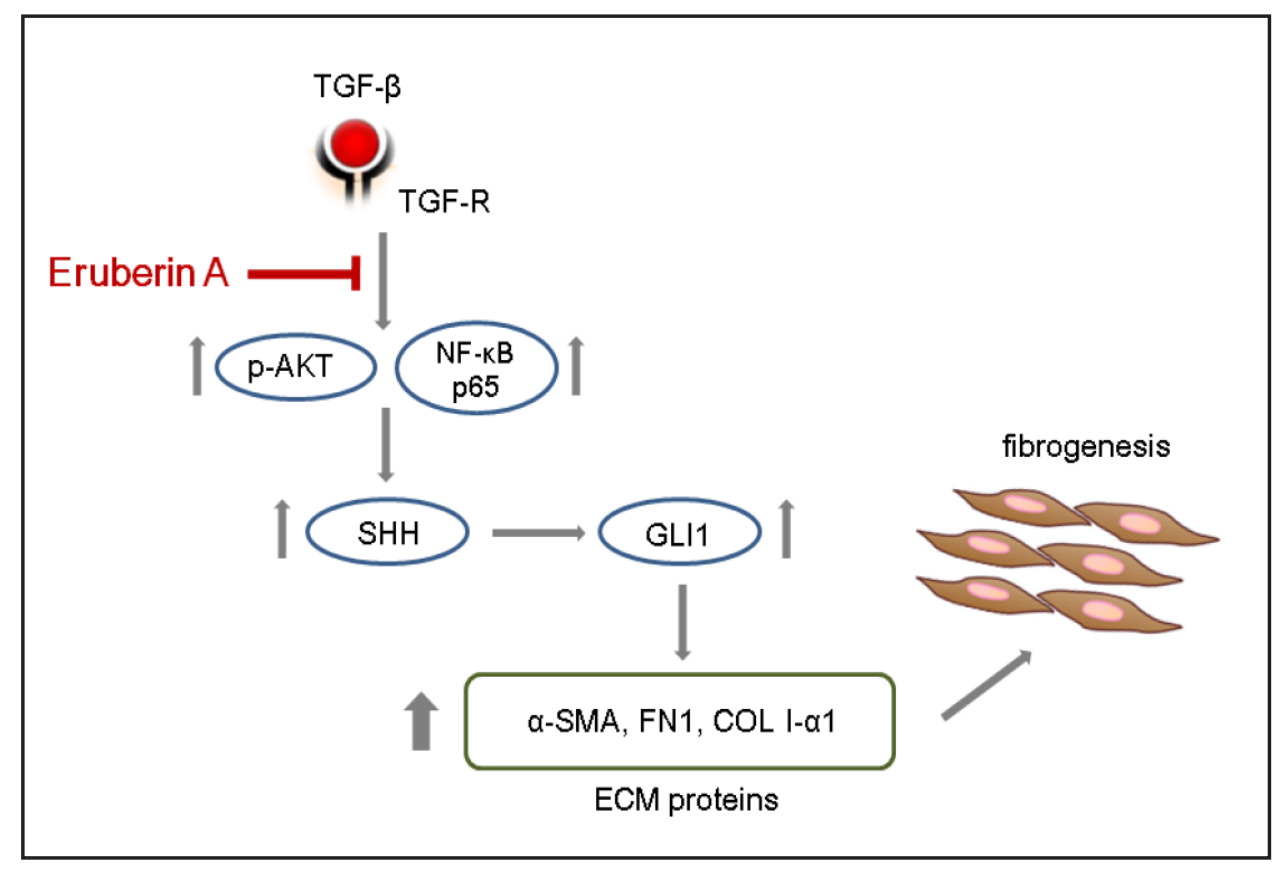

signaling had been observed in mice with cerulein-induced pancreatic fibrosis [17]. The reduction of ECM proteins and fibrotic filament $\alpha$-SMA in LTC-14 cells by RNAi-depletion of Shh further elucidated the promoting role of SHH signaling in fibrogenesis. Conversely, the direct attenuation of expression levels of SHH and GLI1 uncovers the nature of eruberin A as a SHH inhibitor in PSCs. However, SHH is suggested as a downstream target gene of NF$\kappa \mathrm{B}$ in a number of cellular responses including fibrogenesis. A notable decreased nuclear expression of NF- $\kappa B$, thus, was expectedly observed in LTC-14 cells treated with eruberin A. In line with previous findings, the chemical structures of flavanol glycosides and derivatives may be indicative of their pharmacological properties on modulating the activation of NF- $\mathrm{KB}$. Chen $\mathrm{J}$ et al demonstrated that flavanol glycosides exert antioxidant activities and vascular protective potential in diabetic mice via the suppression of the NF- $\mathrm{KB}$ signaling pathway [21] whereas Dell'agli $M$ and colleagues showed that catechins, compounds of flavanol derivatives, lowered MMP9 secretion via inhibiting NF- $\kappa B$ activation [26]. Apart from fibrosis and pancreatitis, SHH signaling also plays important roles in some intercalating pathologies such as pancreatic tumorgenesis, metastasis and invasion $[27,28]$. In this regard, a SHH signaling-oriented therapeutic approach may serve as an effective remedy for pancreatitis, fibrosis as well as PDAC.

A large body of reports demonstrated that PI3K/AKT signaling pathway was highly associated with cell proliferation, inflammatory responses, tumorgenesis and metastasis. For instance, increased AKT phosphorylation enhanced proliferation and invasiveness of human pancreatic cancer cells [29] and promoted activation of hepatic stellate cells [30] whereas aberrant activation of PI3K/AKT has been observed in patients with advanced enteropancreatic neuroendocrine tumors [31,32]. Some recent reports suggested that the transcription factor NF- $\kappa \mathrm{B}$ was negatively modulated in response to the down-regulation of the PI3K/AKT pathway [12, 33, 34]. In this study, upon the application of LY249002 (a PI3K inhibitor) or SC-66 (an AKT inhibitor), the expression levels of p-AKT and nuclear NF- $\mathrm{KB}$ p65 in LTC-14 cells were remarkably decreased followed by a loss of fibrotic filament $\alpha$-SMA and ECM proteins. Our results support the previous findings that PI3K/AKT signaling pathway plays a role in fibrogenesis and modulates the transcription factor NF- $\kappa B$. Most importantly, the activation of both p-AKT and NF-кB in LTC-14 cells was significantly inhibited by the treatment of eruberin A. Collectively, we deduced that the anti-fibrotic effects of eruberin $\mathrm{A}$ involved the suppression of the PI3K/AKT/NF- $\mathrm{B}$ pathway (Fig. 8). 


\section{Cellular Physiology Cell Physiol Biochem 2015;36:2433-2446 \begin{tabular}{ll|l} 
and & DOI.1159/000430204 & $\begin{array}{l}\text { O 2015 S. Karger AG, Basel } \\
\text { www.karger.com/cpb }\end{array}$ \\
\cline { 2 - 3 }
\end{tabular} Tsang et al.: Eruberin A Attenuates Fibrotic Mediators}

In conclusion, the current study demonstrated that eruberin A suppressed the production of ECM proteins FN1 and COL I- $\alpha 1$ and the formation of fibrotic filament $\alpha$-SMA in vitro by modulating SHH signaling components, by which an attenuation of the PI3K/AKT/ $\mathrm{NF}-\kappa \mathrm{B}$ pathway was involved. Thus, the cellular regulatory mechanisms of fibrotic mediators in PSCs and PDAC cells have been partially revealed.

\section{Disclosure Statement}

The authors filed a US non-provisional patent application titled "Use of a flavanol glycoside for suppressing activation of stellate cells" on May 22, 2013 with an application number US 13/899,713.

\section{Acknowledgement}

Eruberin A was kindly provided by Dr. Y-G Chen from Yunnan Normal University, Kunming, China. We are grateful to Prof. R Jaster from University Hospital of Rostock, Rostock, Germany for providing us the LTC-14 cell line. This work was supported by the National Natural Science Foundation of China (Young Scientist Project \#81400666) and Hong Kong Baptist University (Interdisciplinary Research Matching Scheme \#RC-IRMS/12-13/03).

\section{References}

1 Patel M, Fine DR: Fibrogenesis in the pancreas after acinar cell injury. Scand J Surg 2005;94:108-111.

2 Witt H: Chronic pancreatitis and cystic fibrosis. Gut 2003;52 Suppl 2:ii31-41.

3 Erkan M, Adler G, Apte MV, Bachem MG, Buchholz M, Detlefsen S, Esposito I, Friess H, Gress TM, Habisch HJ, Hwang RF, Jaster R, Kleeff J, Klöppel G, Kordes C, Logsdon CD, Masamune A, Michalski CW, Oh J, Phillips PA, Pinzani M, Reiser-Erkan C, Tsukamoto H, Wilson J: StellaTUM: current consensus and discussion on pancreatic stellate cell research. Gut 2012;61:172-178.

4 Apte MV, Haber PS, Applegate TL, Norton ID, McCaughan GW, Korsten MA, Pirola RC, Wilson JS: Periacinar stellate shaped cells in rat pancreas: identification, isolation, and culture. Gut 1998;43:128-133.

$5 \quad$ Phillips PA, McCarroll JA, Park S, Wu MJ, Pirola R, Korsten M, Wilson JS, Apte MV: Rat pancreatic stellate cells secrete matrix metalloproteinases: implications for extracellular matrix turnover. Gut 2003;52:275282.

6 Apte MV, Park S, Phillips PA, Santucci N, Goldstein D, Kumar RK, Ramm GA, Buchler M, Friess H, McCarroll JA, Keogh G, Merrett N, Pirola R, Wilson JS: Desmoplastic reaction in pancreatic cancer: role of pancreatic stellate cells. Pancreas 2004;29:179-187.

7 Yoo BM, Yeo M, Oh TY, Choi JH, Kim WW, Kim JH, Cho SW, Kim SJ, Hahm KB: Amelioration of pancreatic fibrosis in mice with defective TGF-beta signaling. Pancreas 2005;30:e71-79.

8 Hu Q, Noor M, Wong YF, Hylands PJ, Simmonds MS, Xu Q, Jiang D, Hendry BM, Xu Q: In vitro anti-fibrotic activities of herbal compounds and herbs. Nephrol Dial Transplant 2009;24:3033-3041.

9 van Laethem JL, Deviere J, Resibois A, Rickaert F, Vertongen P, Ohtani H, Cremer M, Miyazono K, Robberecht P: Localization of transforming growth factor beta 1 and its latent binding protein in human chronic pancreatitis. Gastroenterology 1995;108:1873-1881.

10 Schneider E, Schmid-Kotsas A, Zhao J, Weidenbach H, Schmid RM, Menke A, Adler G, Waltenberger J, Grünert A, Bachem MG: Identification of mediators stimulating proliferation and matrix synthesis of rat pancreatic stellate cells. Am J Physiol Cell Physiol 2001;281:C532-543.

11 Tang D, Wang D, Yuan Z, Xue X, Zhang Y, An Y, Chen J, Tu M, Lu Z, Wei J, Jiang K, Miao Y: Persistent activation of pancreatic stellate cells creates a microenvironment favorable for the malignant behavior of pancreatic ductal adenocarcinoma. Int J Cancer 2013;132:993-1003.

12 Gilmore TD: Introduction to NF-kappaB: players, pathways, perspectives. Oncogene 2006;25:6680-6684.

13 Dolcet X, Llobet D, Pallares J, Matias-Guiu X: NF-kB in development and progression of human cancer. Virchows Arch 2005;446:475-482. 


\section{Cellular Physiology Cell Physiol Biochem 2015;36:2433-2446 \begin{tabular}{l|l|l}
\hline DOI: 10.1159/000430204 & C 2015 S. Karger AG, Basel
\end{tabular} \\ Tsang et al.: Eruberin A Attenuates Fibrotic Mediators}

14 Hayden MS, Ghosh S: Signaling to NF-kappaB. Genes Dev 2004;18:2195-2224.

15 Chow JY, Ban M, Wu HL, Nguyen F, Huang M, Chung H, Dong H, Carethers JM: TGF-beta downregulates PTEN via activation of NF-kappaB in pancreatic cancer cells. Am J Physiol Gastrointest Liver Physiol 2010;298:G275-282.

16 Song L, Liu L, Wu Z, Li Y, Ying Z, Lin C, Wu J, Hu B, Cheng SY, Li M, Li J: TGF-beta induces miR-182 to sustain NF-kappaB activation in glioma subsets. J Clin Invest 2012;122:3563-3578.

17 Tsang SW, Zhang H, Lin C, Xiao H, Wong M, Shang H, Yang ZJ, Lu A, Yung KK, Bian Z: Rhein, a natural anthraquinone derivative, attenuates the activation of pancreatic stellate cells and ameliorates pancreatic fibrosis in mice with experimental chronic pancreatitis. PLoS One 2013;8(12):e82201.

18 Tsang SW, Bian ZX: Anti-fibrotic and anti-tumorigenic effects of rhein, a natural anthraquinnone derivative, in mammalian stellate and carcinoma cells. Phytother Res 2015;29(3):407-414.

19 Thelypteridaceae: Flora of China. Science Press (Beijing), 2013, vol 2-3, pp 385, 390, 392.

20 Zhao Z, Ruan J, Jin J, Zou J, Zhou D, Fang W, Zeng F: Flavan-4-ol Glycosides from the Rhizomes of Abacopteris penangiana. J Nat Prod 2006;69:265-268.

21 Chen J, Chen X, Lei Y, Wei H, Xiong C, Liu Y, Fu W, Ruan J: Vascular protective potential of the total flavanol glycosides from Abacopteris penangiana via modulating nuclear transcription factor-kappaB signaling pathway and oxidative stress. J Ethnopharmacol 2011;136:217-223.

22 Fang JB, Chen JC, Duan HQ: Constituents from Abacopteris penangiana and their cytotoxicity activity. Chinese Traditional and Herbal Drugs 2010;10:1601-1616.

23 Sparmann G, Hohenadl C, Tornoe J, Jaster R, Fitzner B, Koczan D, Thiesen HJ, Glass A, Winder D, Liebe S, Emmrich J: Generation and characterization of immortalized rat pancreatic stellate cells. Am J Physiol Gastrointest Liver Physiol 2004;287:G211-219.

24 Tanaka N, Murakami T, Wada H, Gutierrez AB, Saiki Y, Chen CM: Chemical and Chemotaxonomical Studies of Filices. LXI. Chemical studies on the constituents of Pronephrium triphyllum HOLLT. Chem Pharm Bull 1985;33:5231-5238.

25 Tsang SW, Zhang H, Lin Z, Mu H, Bian ZX: Anti-fibrotic effect of trans-resveratrol on pancreatic stellate cells. Biomed Pharmacother 2015;71:91-97.

26 Dell'agli M, Bellosta S, Rizzi L, Galli GV, Canavesi M, Rota F, Parente R, Bosisio E, Romeo S: A structureactivity study for the inhibition of metalloproteinase- 9 activity and gene expression by analogues of gallocatechin-3-gallate. Cell Mol Life Sci 2005;62:2896-2903.

27 Walter K, Omura N, Hong SM, Griffith M, Vincent A, Borges M, Goggins M: Overexpression of smoothened activates the sonic hedgehog signaling pathway in pancreatic cancer-associated fibroblasts. Clin Cancer Res 2010;16:1781-1789.

28 Li SH, Fu J, Watkins DN, Srivastava RK, Shankar S: Sulforaphane regulates self-renewal of pancreatic cancer stem cells through the modulation of Sonic hedgehog-GLI pathway. Mol Cell Biochem 2013;373:217-227.

29 Teranishi T, Saruyama M, Kanehara M: Seed-mediated synthesis of metal sulfide patchy nanoparticles. Nanoscale 2009;1:225-228.

30 Xiao Y, Qu C, Ge W, Wang B, Wu J, Xu L, Chen Y: Depletion of thymosin $\beta 4$ promotes the proliferation, migration, and activation of human hepatic stellate cells. Cell Physiol Biochem 2014;34(2):356-267.

31 Shah T, Hochhauser D, Frow R, Quaglia A, Dhillon AP, Caplin ME: Epidermal growth factor receptor expression and activation in neuroendocrine tumours. J Neuroendocrinol 2006;18:355-360.

32 Zikusoka MN, Kidd M, Eick G, Latich I, Modlin IM: The molecular genetics of gastroenteropancreatic neuroendocrine tumors. Cancer 2005;104:2292-2309.

33 Dilly AK, Ekambaram P, Guo Y, Cai Y, Tucker SC, Fridman R, Kandouz M, Honn KV: Platelet-type 12-lipoxygenase induces MMP9 expression and cellular invasion via activation of PI3K/Akt/NF-kappaB. Int J Cancer 2013;133:1784-1791.

34 Qiao Q, Jiang Y, Li G: Inhibition of the PI3K/AKT-NF-kappaB pathway with curcumin enhanced radiationinduced apoptosis in human Burkitt's lymphoma. J Pharmacol Sci 2013;121:247-256. 